\title{
Carbon aerosols and atmospheric photochemistry
}

\author{
D. J. Lary, ${ }^{1}$ A. M. Lee, ${ }^{1}$ R. Toumi, ${ }^{2}$ M. J. Newchurch, ${ }^{3}$ M. Pirre,${ }^{4}$ and J. B. \\ Renard $^{4}$
}

\begin{abstract}
Carbon aerosols are produced by all combustion processes. This paper investigates some possible effects of heterogeneous reduction of atmospheric constituents on carbon aerosols. Reduction of $\mathrm{HNO}_{3}, \mathrm{NO}_{2}$, and $\mathrm{O}_{3}$ on carbon aerosols may be an important effect of increased air traffic that has not been considered to date. It is shown that if $\mathrm{HNO}_{3}, \mathrm{NO}_{2}$ and $\mathrm{O}_{3}$ are heterogeneously reduced on atmospheric amorphous carbon aerosols, then a significant, lower stratospheric ozone loss mechanism could exist. This ozone loss mechanism is almost independent of temperature and does not require the presence of sunlight. The mechanism can operate at all latitudes where amorphous carbon aerosols are present. The relative importance of the mechanism increases with nightlength. The reduction of $\mathrm{HNO}_{3}$ on carbon aerosols could also be a significant renoxification process wherever carbon aerosols are present. Owing to the very different soot levels in the two hemispheres, this implies that there should be a hemispheric assymetry in the role of these mechanisms. The renoxification leads to simulated tropospheric $\mathrm{HNO}_{3} / \mathrm{NO}_{x}$ ratios that are close to those observed. In contrast to the stratospheric response, the tropospheric production of $\mathrm{NO}_{x}$ due to the reduction of $\mathrm{HNO}_{3}$ would lead to tropospheric ozone production.
\end{abstract}

\section{Introduction}

The recent World Meteorological Organization (WMO) assessments [WMO, 1992, 1994] reported that for the first time there were statistically significant decreases in ozone in all seasons in both the northern and southern hemispheres at mid latitudes and high latitudes during the 1980s, and that most of this decrease occurred in the lower stratosphere. This has also been supported by trends derived from ozonesondes [Logan, 1994]. If this ozone loss is due to in situ chemistry, the mechanism involved must be able to operate at all temperatures.

In contrast to the ozone loss that occurs in the stratosphere, there is an observed ozone increase in the troposphere. This paper examines the role of amorphous carbon aerosols in reducing atmospheric constituents. This is relevant to several issues, including the following: first, midlatitude, lower stratospheric ozone loss and its temperature, altitude, and seasonal dependence; second, to atmospheric renoxification, where models gen-

\footnotetext{
${ }^{1}$ Centre For Atmospheric Science, Cambridge University, Cambridge, England.

${ }^{2}$ Department of Physics, Imperial College, London, England.

${ }^{3}$ Earth System Science Laboratory, University of Alabama in Huntsville.

${ }^{4}$ Laboratoire de Phsyique et Chimie de l'Environnement. CNRS, Orleans, France.
}

Copyright 1997 by the American Geophysical Union.

Paper number 96JD02969.

0148-0227/97/96JD-02969\$09.00 erally overestimate the $\mathrm{HNO}_{3}$ abundance, particularly in the troposphere (e.g. Chatfield, 1995); third, to tropospheric ozone production.

\section{Heterogeneous Reactions on Carbon Aerosols}

Thlıbi and Petut [1994] studied the interaction of soot with $\mathrm{NO}_{y}$. They found that hydrogen atoms on the soot surface play an important role in the interaction, HCN being observed in the desorbed products. Thlibi and Petit [1994] found that at the temperatures close to those found in the atmosphere the gas/solid interaction quickly converted both $\mathrm{NO}_{2}$ and $\mathrm{HNO}_{3}$ into $\mathrm{NO}$. $\mathrm{NO}$ was the main product formed, with $\mathrm{CO}_{2}, \mathrm{CO}, \mathrm{N}_{2}$, and $\mathrm{N}_{2} \mathrm{O}$ being minor products. (It would therefore be interesting to see if slightly larger $\mathrm{N}_{2} \mathrm{O}$ concentrations are observed in aircraft flight corridors.) NO reacted on the soot at a rate which was at least 1 order of magnitude slower than both $\mathrm{NO}_{2}$ and $\mathrm{HNO}_{3}$.

In the presence of oxygen, NO is expected to be partially converted into $\mathrm{NO}_{2}$ [Thlibi and Petit, 1994]. It is likely that three of the $\mathrm{NO}_{y} /$ soot reactions that will be important for the atmosphere are

$$
\begin{array}{ccc}
\mathrm{HNO}_{3} & \stackrel{\text { carbon }}{\longrightarrow} & \mathrm{NO}_{2} \\
\mathrm{HNO}_{3} & \stackrel{\text { carbon }}{\longrightarrow} & \mathrm{NO} \\
\mathrm{NO}_{2} & \stackrel{\text { carbon }}{\longrightarrow} & \mathrm{NO}
\end{array}
$$

The exact fate of the oxygen and hydrogen atoms in these processes is important and needs to be examined 
further. Direct ozone loss can also occur on carbon aerosols.

$$
\mathrm{O}_{3} \stackrel{\text { carbon }}{\longrightarrow} \mathrm{O}_{2}
$$

Tabor et al. [1993, 1994] measured the accommodation coefficient for $\mathrm{NO}_{2}$ uptake on solid amorphous carbon. Like Thlibi and Petit [1994], they found that $\mathrm{NO}_{2}$ was reduced on the solid amorphous carbon to yield NO. If atmospheric $\mathrm{NO}_{2}$ is reduced in this way on solid amorphous carbon then it represents a significant nighttime loss of $\mathrm{O}_{3}$ as the reduction of $\mathrm{NO}_{2}$ is actually the rate limiting step of the catalytic cycle

$$
\begin{array}{rll}
\mathrm{NO}_{2} & \stackrel{\text { carbon }}{\longrightarrow} & \mathrm{NO} \\
\mathrm{NO}+\mathrm{O}_{3} & \longrightarrow & \mathrm{NO}_{2}+\mathrm{O}_{2} \\
\mathrm{NetO}_{3} & \stackrel{\text { carbon }}{\longrightarrow} & \mathrm{O}_{2}
\end{array}
$$

This ozone loss cycle is unusual in that it can occur during the night. It does not require the presence of sunlight. However, the cycle also proceeds during the day. The cycle has little effect on other $\mathrm{NO}_{y}$ species because as soon as the NO is formed it is almost immediately converted back in to $\mathrm{NO}_{2}$. This cycle should play a role whenever there are carbon aerosols. There is, of course, the possibility that the active sites for physisorption will become saturated and so will take no further part in the heterogeneous process. If this is the case, then desorption could be initiated by heating and the presence of UV light. Another important issue is whether oxygen atoms are produced; if they are, this may partially or completely negate the ozone loss mechanism just described. These are all areas that need to be further investigated.

Tabor et al. [1993, 1994] report an accommodation coefficient for $\mathrm{NO}_{2}$ uptake on solid amorphous carbon of $(4.8 \pm 0.6) \times 10^{-2}$. They found that the only major product was NO corresponding to about $60 \%$ of the $\mathrm{NO}_{2}$ adsorbed on the surface. Consequently, in this study, a $\gamma$ value for the heterogeneous reduction of $\mathrm{NO}_{2}$ to NO of $2.8 \times 10^{-2}$ was used. Thlibi and Petit [1994] found that the reduction of $\mathrm{HNO}_{3}$ into $\mathrm{NO}$ also occurs on carbon aerosols. Rogaski et al. [1996, also personal communication, 1996] measured an uptake value of $(3.8 \pm 0.8) \times 10^{-2}$. For the length of their experiments $(<45 \mathrm{~min})$ they observed no time dependence. They found that the major products of the heterogeneous interaction of $\mathrm{HNO}_{3}$ with soot were $\mathrm{H}_{2} \mathrm{O}, \mathrm{NO}_{2}$, and NO. They looked for $\mathrm{O}_{2}$ and $\mathrm{N}_{2}$ production but did not observe any. They determined the product yield for each species. $\mathrm{NO}_{2}$ was the dominant $\mathrm{NO}_{x}$ product. It was a factor of 5 larger than the NO yield. They measured that, on average, for every three $\mathrm{HNO}_{3}$ molecules lost to the surface, two $\mathrm{NO}_{x}$ molecules are released to the atmosphere. Consequently, in this study, a sticking coefficient of $4.2 \times 10^{-3}$ was used for $\mathrm{HNO}_{3}$ to $\mathrm{NO}$ conversion and a sticking coefficient of $2.1 \times 10^{-2}$ was used for $\mathrm{HNO}_{3}$ to $\mathrm{NO}_{2}$ conversion.
The evaluation of DeMore et al. [1994] recommends a reaction probability for $\mathrm{O}_{3}$ on carbon/soot of $3 \mathrm{x}$ $10^{-2}$. Fendel and Ott [1993] report fast $\mathrm{O}_{3}$ loss on 10 to $100 \mathrm{~nm}$ solid carbon agglomerates, with an estimated reaction probability near $3 \times 10^{-2}$. Fendel et al. [1995] report that submicron carbon or iron aerosol particles destroy ozone efficiently; the sticking coefficient of $\mathrm{O}_{3}$ to the particles is of the order of $10^{-4}$. They conclude that particles present in the stratosphere may represent a significant sink for $\mathrm{O}_{3}$. Smith et al. [1988] report that the ozone/soot reaction is first order in ozone, with $\mathrm{CO}, \mathrm{CO}_{2}$ and $\mathrm{H}_{2} \mathrm{O}$ the only stable gaseous products. Stephens et al. [1986] measured $\mathrm{CO}, \mathrm{CO}_{2}$ and $\mathrm{O}_{2}$ as products with an $\mathrm{O}_{2}$ produced for each $\mathrm{O}_{3}$ reacted. Stephens et al. [1986] measured uptake coefficients which varied from $10^{-3}$ to $10^{-5}$ depending on the carbon sample and $\mathrm{O}_{3}$ exposure. The $\mathrm{O}_{3}$ reaction probability on carbon aerosols is clearly dependent on the carbon aerosol's surface history. Consequently, in this study, a sticking coefficient of $1 \times 10^{-5}$ was used for $\mathrm{O}_{3}$ to $\mathrm{O}_{2}$ conversion as a lower limit, so that the effects on the ozone should be at least those reported here, and, in fact, will probably be greater.

\section{Production, Transport, and Characteristics of Carbon Aerosols}

Atmospheric soot particles are produced by the incomplete combustion of fossil and other fuels. Combustion generated aerosols can affect the atmosphere in two main ways, via light absorption (e.g., Shaw and Stamnes, 1980; Porch and MacCracken, 1982; Cess, 1983; Rosen and Hansen, 1984) and via heterogeneous reactions on their surfaces (e.g., Tabor et al., 1993, 1994). Heterogeneous reduction of atmospheric constituents on carbon aerosols is a possibility that has been largely overlooked up until now, but it could actually be very important.

The present subsonic air traffic occurs mainly in the northern hemisphere, with about $30 \%$ to $50 \%$ flying above the tropopause [Schumann, 1994]. Future highspeed civil transport (HSCT) systems have been proposed to fly in the middle and lower stratosphere. In 1990 , about $176 \mathrm{Mt}$ of aviation fuel was used. To put this into context, this aviation fuel constitutes about $6 \%$ of all petrol products and provides about $3 \%$ of the $\mathrm{CO}_{2}$ released by the burning of fossil fuels. Global fuel consumption grows by about $3 \%$ per year, with a doubling expected within the next 18 to 25 years. Present emissions by space flight are about a factor of 10,000 times smaller than those from aviation. The present aviation traffic has already caused a considerable increase in $\mathrm{NO}_{x}$ concentrations (between $30 \%$ to $100 \%$ ) in the upper troposphere along main flight routes [Schumann, 1994].

Graphitic carbon particles can be transported on the global scale and so are able to reach remote regions. Long-range transport of graphitic carbon particles of 
at least $2000 \mathrm{~km}$ from the closest significant source region has been observed at ground level stations throughout the western Arctic [Stonehouse, 1986; Rosen et al., 1981; Heintzenberg, 1982; Rosen and Novakov, 1983]. Trace element and meteorological analyses suggest that even longer-range transport from midlatitudes between 5,000 and $10,000 \mathrm{~km}$ away had taken place [Rahn and McCaffrey, 1980; Barrie et al., 1981].

Horizontal profiles of graphitic carbon particles have been provided by missions such as the National Oceanographic and Atmospheric Administration (NOAA) airplane sampling programme during March and April 1983 [Schnell et al., 1994; Rosen and Hansen, 1984; Hansen and Rosen, 1984]. It has been found that graphitic carbon particles are present throughout the arctic troposphere with upper layers typically containing more particles than at ground level.

Pusechel et al. [1992] reported that upper tropospheric aircraft emissions of soot presently represent approximately $0.3 \%$ by mass of the background stratospheric aerosols. Blake and Kato [1995] recently presented an overview of black carbon soot measurements made in the upper troposphere and lower stratosphere, between $45^{\circ} \mathrm{S}$ and $90^{\circ} \mathrm{N}$, and they confirm this finding They also point out that for volcanically quiescent periods, if surface areas are considered instead of mass, the surface area of carbon aerosols is comparable to that of sulphate aerosols. In fact, the surface area of carbon aerosols may be more than that of sulphate aerosols during volcanically quiescent periods. This is because carbon aerosols are typically not spherical, but rather have a fractal geometry. Blake and Kato [1995] considered two extreme cases and calculated the surface area of the carbon particles as if they were all spheres or as if they had a purely fractal geometry. The fractal surface area calculation gave an area that was 30 times greater than the area calculated if all the carbon aerosols were assumed to be $20 \mathrm{~nm}$ spheres.

Colbeck and Nyekr [1992] presented a review of fractal structures as applied to environmental aerosols. They point out that the atmospheric lifetime of particles is dependent on their terminal velocity, which is related to the fractal dimension of the particles. Many natural objects such as coastlines and clouds may be represented by fractal theory. A basic property of fractal objects is that they obey the scaling relationship:

$$
N \propto R^{D}
$$

where $\mathrm{N}$ is the number of features, $\mathrm{R}$ is the resolution of measurements, and D is the fractal dimension of the object. Fractal clusters sediment more slowly than compact spheres of the same mass. Berry [1989] calculated that clusters composed of 1000 individual spherules of radius $20 \mathrm{~nm}$ fall at approximately $100 \mathrm{~m} \mathrm{yr}^{-1}$ if $\mathrm{D}=1.8$ as compared with $1 \mathrm{~km} \mathrm{yr}^{-1}$ for solid clusters $(D=3)$.

Blake and Kato [1995] state that the carbon aerosol distributions they presented did not account for soot that had been entrained within sulphuric acid droplets.
It is rather surprising that most of the soot aerosols are not actually entrained in sulphate aerosols. Blake and Kato [1995] speculated that aircraft-generated aerosols may constitute poor condensation nuclei. However, Kärcher et al. [1996] find strong evidence that aircraft soot is responsible for the buildup of visible contrails. Kärcher et al. [1996] show that the observation is consistent with model results under the assumption that soot gets coated by a liquid $\mathrm{H}_{2} \mathrm{SO}_{4} / \mathrm{H}_{2} \mathrm{O}$ solution, possibly also containing $\mathrm{HNO}_{3}$, and that the soot core triggers heterogeneous freezing of water ice during plume cooling. They found that the observations cannot be explained by assuming dry soot upon which ice nucleates heterogeneously, directly from the vapor phase. These results strongly point toward the fact that aircraft soot leaves the jet engines already entrained in a liquid sulfuric acid solution. This is also very likely to be true in cases where no visible ice contrails form. Even if soot would be emitted without coating, quick coagulation processes with in situ nucleated $\mathrm{H}_{2} \mathrm{SO}_{4} / \mathrm{H}_{2} \mathrm{O}$ aerosols might entrain them into droplets. This would be similar to the Kuwaiti oil fire plumes studied by, for example, Parungo et al. [1992], where carbon had become entrained within liquid droplets. It could be that the soot is entrained in droplets close to the aircraft, but in the far-field situation as measured by Blake and Kato [1995], the soot is no longer entrained within a droplet.

It seems that biomass burning does not contribute significantly to the upper tropospheric, lower stratospheric soot loading. Blake and Kato [1995] found that the measured latitudinal distribution of black carbon soot between 10 and $11 \mathrm{~km}$ covaried with commercial air traffic use, suggesting that aircraft fuel combustion is the principal source of soot at this altitude. In addition, they found that at latitudes where there is a lot of commercial air traffic, significant levels of black carbon soot were measured even at $20 \mathrm{~km}$. This suggests that aircraft-generated soot injected just above the tropopause may be transported to higher altitudes. By assigning upper and lower estimates on the total fuel burned in the stratosphere by aircraft and comparing this to the measured soot concentrations, a black carbon soot residence time of between 4 and 12 months was derived by Blake and Kato [1995].

Baumgardner et al. [1996] report results from a new instrument which can simultaneously measure aerosol diameter between 0.4 and $10 \mu \mathrm{m}$ and which was recently flown on the NASA ER2 aircraft during a stratospheric measurement campaign. The measured stratospheric refractive indices do not agree well with theoretical predictions, and vertical profiles suggest the presence of nonspherical or absorbing particles in the altitude range of 7 to $9 \mathrm{~km}$. One possibility is that Baumgardner et al. [1996] observed carbon aerosols.

In the Arctic boundary layer a low $\mathrm{HNO}_{3} / \mathrm{NO}_{x}$ ratio has been inferred from measurements. Therefore, if the soot reduction actually occurs, since the Arctic is where soot accumulates, we would expect to see the low values 
that are seen. The observations therefore subjectively support the reduction of $\mathrm{HNO}_{3}$ on soot.

These findings point to the potential importance of $\mathrm{NO}_{y}$ /amorphous carbon interactions on the local and global scale in the stratosphere and the troposphere. If the aviation fuel consumption is set to double in the next 18 to 25 years, it is likely that the carbon surface area will also double, while increases of up to a factor of 10 could occur in flight corridors [WMO, 1994]. This opens the possibility that on the hemispheric scale the carbon surface area could be double that of the background sulphate aerosol surface area during volcanically quiescent periods, and 10 times that of the background sulphate aerosol surface area in flight corridors. Such a large surface area could therefore be a potentially important site for heterogeneous atmospheric chemistry, which really should be thoroughly investigated with a sense of urgency.

It is not only nitrogen species that could be reduced on carbon aerosols. For example, $\mathrm{HOCl}$ could be reduced to $\mathrm{HCl}$, and $\mathrm{HOBr}$ could be reduced to $\mathrm{HBr}$. This could be significant in polar regions, where the production of $\mathrm{HCl}$ can become the rate limiting step for further chlorine activation. These processes also need detailed examination.

\section{Comparison With Observations}

Since there is uncertainty associated with the rate at which $\mathrm{HNO}_{3}$ and $\mathrm{NO}_{2}$ is reduced on carbon aerosols, this section compares some observations with model calculations that include the reduction of $\mathrm{HNO}_{3}$ and $\mathrm{NO}_{2}$ on carbon aerosols.

\section{SESAME Comparison}

Figure 1 shows three simulations that were performed with a three-dimensional chemical transport model [Chipperfield et al., 1996], which used meteorological analyses to specify the circulation. The model was integrated for 12 days and used results from a seasonal integration, which had been integrated from November 22, 1994, in order to initialize each simulation. The seasonal integration had been initialized itself from a combination of two-dimensional chemical fields and data from instruments on board the UARS satellite. This integration is presently being used to investigate the anomalously low $\mathrm{O}_{3}$ amounts seen during the 1994/1995 northern winter (as observed by Manney et al. [1996]). The model was sampled during each simulation at the same time and position relevant to measurements of $\mathrm{NO}_{2}$ made by 'Absorption par Minoritaires Ozone et $\mathrm{NO}_{x}$ ' (AMON) at night inside the polar vortex on February 10, 1995, over Kiruna during the Second European Stratospheric Arctic and Mid-latitude Experiment (SESAME)campaign [Hermann et al., 1996].

Simulation A was a control simulation that includes a standard stratospheric chemistry scheme without any

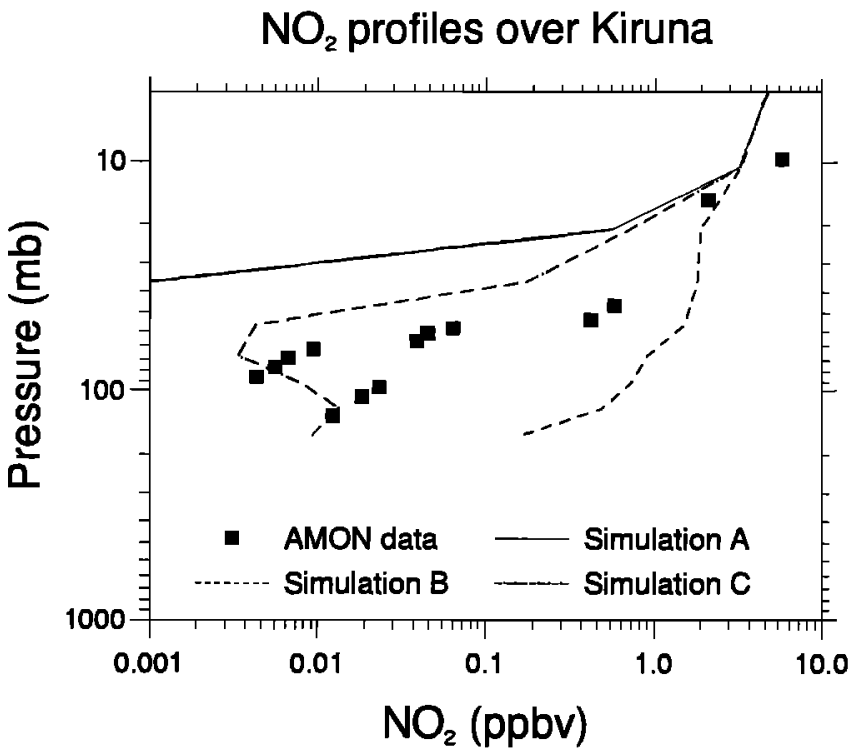

Figure 1. Second European Stratospheric Arctic and Mid-latitude Experiment (SESAME) campaign comparison for the simulated $\mathrm{NO}_{2}$ profiles over Kiruna on February 10,1995 . Simulation A (solid line) was a control simulation which includes a standard stratospheric chemistry scheme. Simulation B (dashed line) included the reduction of $\mathrm{HNO}_{3}$ and $\mathrm{NO}_{2}$ on carbon aerosols, both with a $\gamma$ value of $2.8 \times 10^{-2}$ and a carbon aerosol surface area of $1 \mu \mathrm{m}^{2} / \mathrm{cm}^{3}$. Simulation C (dot-dashed line) was the same as simulation $\mathrm{B}$, except the $\gamma$ value for the reduction of $\mathrm{HNO}_{3}$ was reduced by a factor of 10 .

heterogeneous carbon reactions. Simulation $\mathrm{B}$ includes the reduction of $\mathrm{HNO}_{3}$ and $\mathrm{NO}_{2}$ on carbon aerosols, both with a $\gamma$ value of $2.8 \times 10^{-2}$. Simulation $\mathrm{C}$ was the same as simulation $B$, except the $\gamma$ value for the reduction of $\mathrm{HNO}_{3}$ was reduced by a factor of 10 to a value of $2.8 \times 10^{-3}$. The simulations included the hydrolysis of $\mathrm{N}_{2} \mathrm{O}_{5}, \mathrm{ClONO}_{2}$, and $\mathrm{BrONO}_{2}$ on sulphate aerosols.

Figure 1 shows that the $\mathrm{NO}_{2}$ observations are bracketed by simulations that included heterogeneous carbon reactions (simulations $\mathrm{B}$ and $\mathrm{C}$ ). This is not conclusive proof that the proposed carbon mechanism does occur, but it does make it clear that without some kind of renoxification mechanism, whether it is the mechanism postulated here or some other mechanism, the vertical profiles of $\mathrm{NO}_{2}$ are not well simulated when the hydrolysis of $\mathrm{N}_{2} \mathrm{O}_{5}$ on sulphate aerosols is included. The $\mathrm{N}_{2} \mathrm{O}_{5}$ hydrolysis used in this study is the temperature and composition dependent data recommended by DeMore et al. [1994]. A slower $\mathrm{N}_{2} \mathrm{O}_{5}$ hydrolysis on sulphate aerosols would clearly also increase the simulated $\mathrm{NO}_{x}$ concentration. The required renoxification mechanism needs to operate up to altitudes of around 25 to $30 \mathrm{~km}$. It is unclear what the transport mechanism would be for carbon aerosol to be found at these altitudes within the polar vortex. 

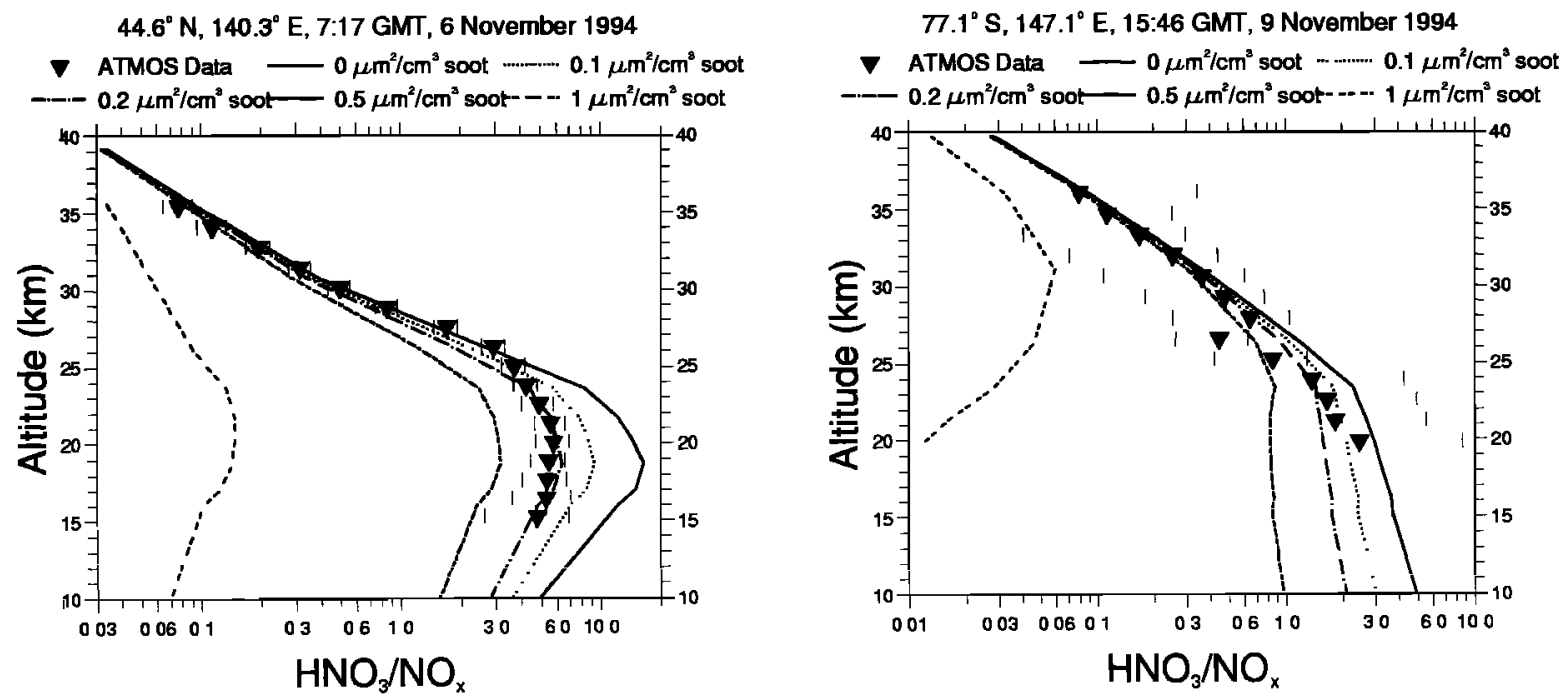

Figure 1. Second European Stratospheric Arctic and Mid-latitude Experiment (SESAME) campaign comparison for the simulated $\mathrm{NO}_{2}$ profiles over Kiruna on February 10, 1995. Simulation A (solid line) was a control simulation which includes a standard stratospheric chemistry scheme. Simulation $\mathrm{B}$ (dashed line) included the reduction of $\mathrm{HNO}_{3}$ and $\mathrm{NO}_{2}$ on carbon aerosols, both with a $\gamma$ value of $2.8 \times 10^{-2}$ and a carbon aerosol surface area of $1 \mu \mathrm{m}^{2} / \mathrm{cm}^{3}$. Simulation $\mathrm{C}$ (dot-dashed line) was the same as simulation $\mathrm{B}$, except the $\gamma$ value for the reduction of $\mathrm{HNO}_{3}$ was reduced by a factor of 10 .

\section{ATMOS ATLAS3 Comparison}

Figure 2 shows the effect of the reduction of $\mathrm{HNO}_{3}$ and $\mathrm{NO}_{2}$ on carbon aerosols (Table 1 ) on the vertical profiles of $\mathrm{NO}_{2}$ and the $\mathrm{HNO}_{3} / \mathrm{NO}_{x}$ ratio in the northern and southern hemispheres compared to the Atmospheric Trace Molecule Spectroscopy (ATMOS) Experiment ATLAS3 measurements made during November 1994. The model used was the AutoChem column model described by Lary [1996] and Lary et al. [1995, 1996]. The column model was run for 7 days starting from the ATMOS ATLAS3 vertical profiles of temperature, $\mathrm{O}_{3}, \mathrm{NO}, \mathrm{NO}_{2}, \mathrm{~N}_{2} \mathrm{O}_{5}, \mathrm{HNO}_{3}, \mathrm{HNO}_{4}, \mathrm{ClONO}_{2}$, $\mathrm{H}_{2} \mathrm{O}, \mathrm{CO}, \mathrm{CO}_{2}, \mathrm{CH}_{4}$ and $\mathrm{N}_{2} \mathrm{O}$. Below $25 \mathrm{~km}$ the diurnal correction to the $\mathrm{NO}_{2}$ profiles is very important [Newchurch et al., 1996].

It can be seen from Figure 2 that above $25 \mathrm{~km}$ there is excellent agreement between the model and the observations in both hemispheres. Below $25 \mathrm{~km}$ there is a slight contrast between the hemispheres. As noted above,

Table 1. Carbon Reduction Reactions Included in This Study

\begin{tabular}{llll}
\hline & Reaction & & $\gamma$ used \\
\hline $\mathrm{HNO}_{3}$ & $\stackrel{\substack{\text { carbon } \\
\mathrm{HNO}_{3}}}{\stackrel{\text { carbon }}{\longrightarrow}}$ & $\mathrm{NO}_{2}$ & $2.1 \times 10^{-2}$ \\
$\mathrm{NO}_{2}$ & $\stackrel{\mathrm{NO}}{\text { carbon }}$ & $\mathrm{NO}$ & $4.2 \times 10^{-3}$ \\
$\mathrm{O}_{3}$ & $\stackrel{\text { carbon }}{\longrightarrow}$ & $\mathrm{O}_{2}$ & $1 \times 10^{-5}$ \\
\hline
\end{tabular}

the northern hemisphere has a larger soot loading than the southern hemisphere. The best agreement between the model simulations and the ATMOS ATLAS3 observations in the northern hemisphere falls close to the simulation with $0.2 \mu \mathrm{m}^{2} / \mathrm{cm}^{3}$. This is in general agreement with the SESAME comparison described above. In contrast, the best agreement between the model simulations and the ATMOS ATLAS3 observations in the southern hemisphere falls close to the simulation with $0.1 \mu \mathrm{m}^{2} / \mathrm{cm}^{3}$. This is consistent with the fact that the southern hemisphere has a lower soot loading. Figure 2 also shows how sensitive the $\mathrm{HNO}_{3} / \mathrm{NO}_{x}$ ratio is to the soot loading. An increase of the soot loading by a factor of 10 reduces the $\mathrm{HNO}_{3} / \mathrm{NO}_{x}$ ratio by a factor of approximately 100 in the lower stratosphere. Including the reduction of $\mathrm{HNO}_{3}$ on soot leads to a simulated $\mathrm{HNO}_{3} / \mathrm{NO}_{x}$ ratio within the observed range of the average free tropospheric ratio of 1-9 reported by Chatfield [1995].

These comparisons do not conclusively prove that the reduction on carbon aerosols actually occurs but they show that the reduction of $\mathrm{NO}_{2}$ and $\mathrm{HNO}_{3}$ is at least consistent with observations and can explain the hemispheric assymetry in the observed $\mathrm{NO}_{2}$ and $\mathrm{HNO}_{3} / \mathrm{NO}_{x}$ ratio vertical profiles. To say this another way, a renoxification mechanism, whether it is the one postulated here or a completely different mechanism, can improve the agreement between observations and simulations of the observed $\mathrm{NO}_{y}$ partitioning if it is more effective in the northern hemisphere than the southern hemisphere.

Toumi et al. [1993] considered the ATMOS $\mathrm{HNO}_{3} /$ $\mathrm{NO}_{x}$ ratio and concluded that the current recommen- 
dations for the sulphate $\mathrm{N}_{2} \mathrm{O}_{5}$ loss are too fast to agree with observations. Considine et al. [1992], studying limb infrared monitor of the stratosphere (LIMS) data, and McElroy et al. [1992] using ATMOS data, also concluded that the current recommendations for the sulphate $\mathrm{N}_{2} \mathrm{O}_{5}$ loss are too fast to agree with observations. Figure 2 shows that including heterogeneous reduction of $\mathrm{HNO}_{3}$ on carbon aerosols improves the agreement between the simulated and observed $\mathrm{HNO}_{3} / \mathrm{NO}_{x}$ ratio in the lower stratosphere of the northern hemisphere by providing a renoxification mechanism. Now that we have seen that the reduction of $\mathrm{HNO}_{3}$ and $\mathrm{NO}_{2}$ is at least consistent with observations, the next section examines in detail the sensitivity of the proposed mechanisms to carbon surface area, temperature, altitude, and day length.

\section{Sensitivity Experiments}

To examine the role of $\mathrm{HNO}_{3}, \mathrm{NO}_{2}$ and $\mathrm{O}_{3}$ reduction on amorphous carbon aerosols in the lower stratosphere and the upper troposphere at mid-latitudes a set of idealised model simulations were performed. The numerical model used for these simulations was AUToCHEM, a model described by Lary [1995] and Lary et al. [1995, 1996] and Fisher and Lary [1995]. In the simulations a stationary air parcel at $45^{\circ} \mathrm{N}$ was considered. The simulations included the hydrolysis of $\mathrm{N}_{2} \mathrm{O}_{5}, \mathrm{ClONO}_{2}$ and $\mathrm{BrONO}_{2}$ on sulphate aerosols.

\section{Carbon Surface Area and Temperature Dependence}

In the first set of sensitivity experiments the temperature of an air parcel at $70 \mathrm{mb}$ at equinox was varied between $200 \mathrm{~K}$ and $240 \mathrm{~K}$ and the amorphous carbon aerosol surface area was varied between 0 and $10 \mu \mathrm{m}^{2} \mathrm{~cm}^{-3}$. For each of these conditions a 7-day simulation was performed.

Although the observed hemispheric average carbon aerosol surface area is typically around $1 \mu \mathrm{m}^{2} \mathrm{~cm}^{-3}$, much higher areas do exist locally, for example, in aircraft wakes. In addition, because it is likely that the carbon aerosol abundance will double over the next 25 years, carbon aerosol areas up to $10 \mu \mathrm{m}^{2} \mathrm{~cm}^{-3}$ were considered.

Figure 3 shows that the heterogeneous reduction of $\mathrm{HNO}_{3}$ on amorphous carbon aerosol is a significant renoxification process than can obviously continue throug out the day. For example, Figure 4 is for midnight. When no carbon aerosols are present, then the simulation predicts that approximately $80 \%$ of $\mathrm{NO}_{y}$ is in the form of $\mathrm{HNO}_{3}$. However, with the assumed $\gamma$ values, increasing the carbon area to just $1 \mu \mathrm{m}^{2} \mathrm{~cm}^{-3}$, a value close to the current hemispheric average, reduces the $\mathrm{HNO}_{3} / \mathrm{NO}_{y}$ ratio to approximately 0.5 . Thus renoxification on carbon aerosols will also be important in the troposphere and could explain the current discrepancy between observed and modeled values of the
$\mathrm{HNO}_{3} / \mathrm{NO}_{y}$ ratio [Chatfield, 1995]. Figure 3 also shows that the heterogeneous reduction of $\mathrm{NO}_{2}$ and $\mathrm{O}_{3}$ on amorphous carbon aerosol is quite rapid. The rate of $\mathrm{O}_{3}$ reduction is likely to be faster than that displayed in Figure 3, as a lower limit $\gamma$ value of only $10^{-5}$ has been used.

Including the heterogeneous reduction of $\mathrm{NO}_{2}$ and $\mathrm{HNO}_{3}$ by amorphous carbon aerosols increases the nighttime NO concentration (Figure 4). Without the heterogeneous reduction of $\mathrm{NO}_{2}$ and $\mathrm{HNO}_{3}$ models predict an $\mathrm{NO} / \mathrm{NO}_{y}$ ratio that is almost zero.

Figure 3 shows that the midnight rate of the heterogeneous reduction of $\mathrm{NO}_{2}$ on amorphous carbon aerosol is a function of both temperature and the amorphous carbon aerosol surface area. The rate varies between $10^{3}$ molecules $\mathrm{cm}^{-3} \mathrm{~s}^{-1}$ for an amorphous carbon aerosol surface area of less than $1 \mu \mathrm{m}^{2} \mathrm{~cm}^{-3}$ and $10^{6}$ molecules $\mathrm{cm}^{-3} \mathrm{~s}^{-1}$ for an amorphous carbon aerosol surface area of $10 \mu \mathrm{m}^{2} \mathrm{~cm}^{-3}$ at $200 \mathrm{~K}$. Since the midnight rate of reaction of $\mathrm{NO}_{2}$ with $\mathrm{O}_{3}$ closely follows the rate of reduction of $\mathrm{NO}_{2}$ to $\mathrm{NO}$ on the amorphous carbon aerosol, it can be seen from Figures 3 and 4 that the reduction of $\mathrm{NO}_{2}$ to $\mathrm{NO}$ on the amorphous carbon aerosol is the rate-limiting step of the catalytic ozone loss cycle mentioned above.

With a reaction probability for $\mathrm{O}_{3}$ of just $10^{-5}$, at low carbon aerosol surface areas the direct loss of $\mathrm{O}_{3}$ on the carbon is likely to be faster than the catalytic loss due to the production of NO (Figure 3 ). For high carbon aerosol surface areas the direct loss of $\mathrm{O}_{3}$ on the carbon is likely to be slower than the catalytic loss due to the production of NO. By way of a comparison, under the same conditions, the corresponding ozone loss rate at noon due to the reaction of $\mathrm{HO}_{2}$ with $\mathrm{O}_{3}$, i.e., the rate of the major ozone loss cycle, is approximately $10^{5}$ molecules $\mathrm{cm}^{-3} \mathrm{~s}^{-1}$ at $200 \mathrm{~K}$, rising to $10^{6}$ molecules $\mathrm{cm}^{-3} \mathrm{~s}^{-1}$ at $240 \mathrm{~K}$. An ozone loss rate that can reach $10^{6}$ molecules $\mathrm{cm}^{-3} \mathrm{~s}^{-1}$ is therefore clearly a significant ozone loss rate.

Figure 3 shows that the midnight rate of the heterogeneous reduction of $\mathrm{HNO}_{3}$ on amorphous carbon aerosol is a function of both temperature and the amorphous carbon aerosol surface area. The rate varies between $3 \times 10^{3}$ molecules $\mathrm{cm}^{-3} \mathrm{~s}^{-1}$ for an amorphous carbon aerosol surface area of less than $1 \mu \mathrm{m}^{2} \mathrm{~cm}^{-3}$ up to $8 \times 10^{3}$ molecules $\mathrm{cm}^{-3} \mathrm{~s}^{-1}$ for an amorphous carbon aerosol surface area of $10 \mu \mathrm{m}^{2} \mathrm{~cm}^{-3}$ at $240 \mathrm{~K}$. This renoxification by the reduction of $\mathrm{HNO}_{3}$ provides additional $\mathrm{NO}_{x}$ which can take part in the catalytic destruction of ozone.

Figure 4 shows that the additional ozone loss caused by the heterogeneous reduction of $\mathrm{HNO}_{3}, \mathrm{NO}_{2}$ and $\mathrm{O}_{3}$ on amorphous carbon aerosol over the 7-day simulation period reaches nearly $3 \%$ (80 ppbv) for an amorphous carbon aerosol surface area of $10 \mu \mathrm{m}^{2} \mathrm{~cm}^{-3}$. It is noteworthy that the additional ozone loss caused by the heterogeneous reduction of $\mathrm{NO}_{2}$ is almost independent of temperature if the $\gamma$ value is not temperature depen- 

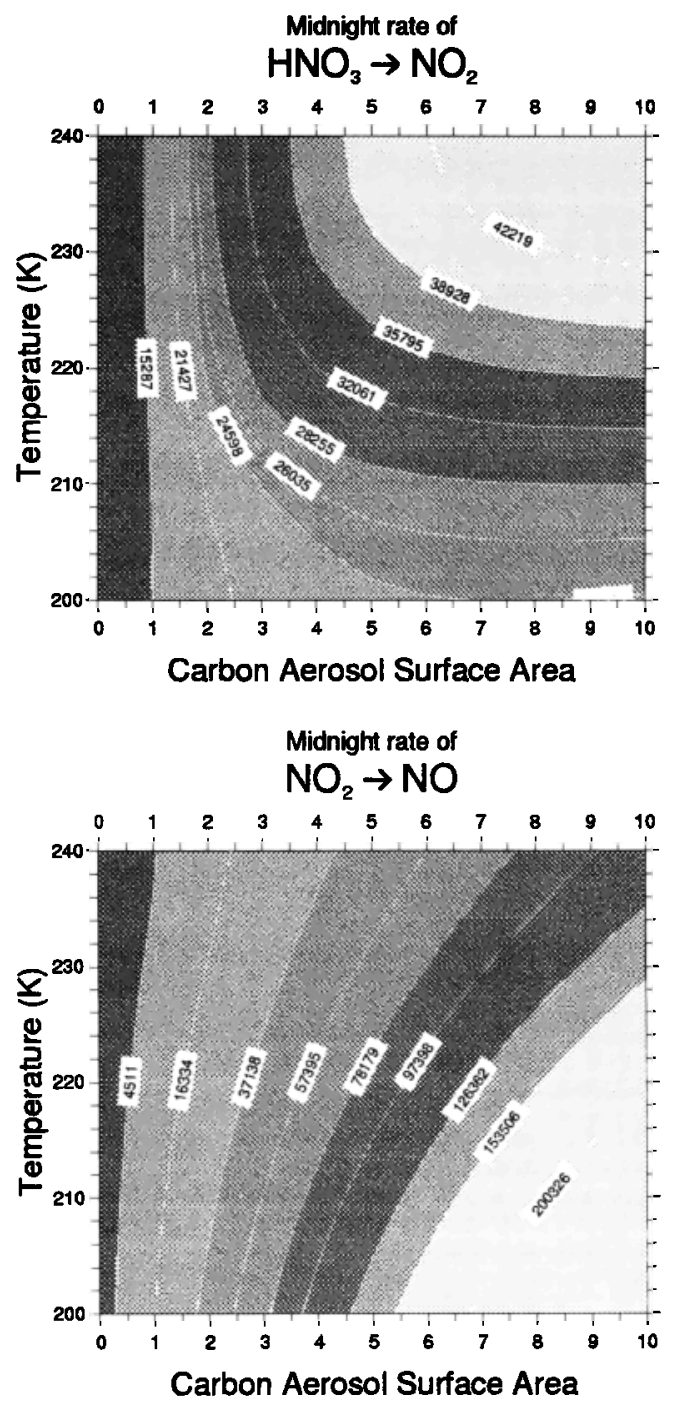
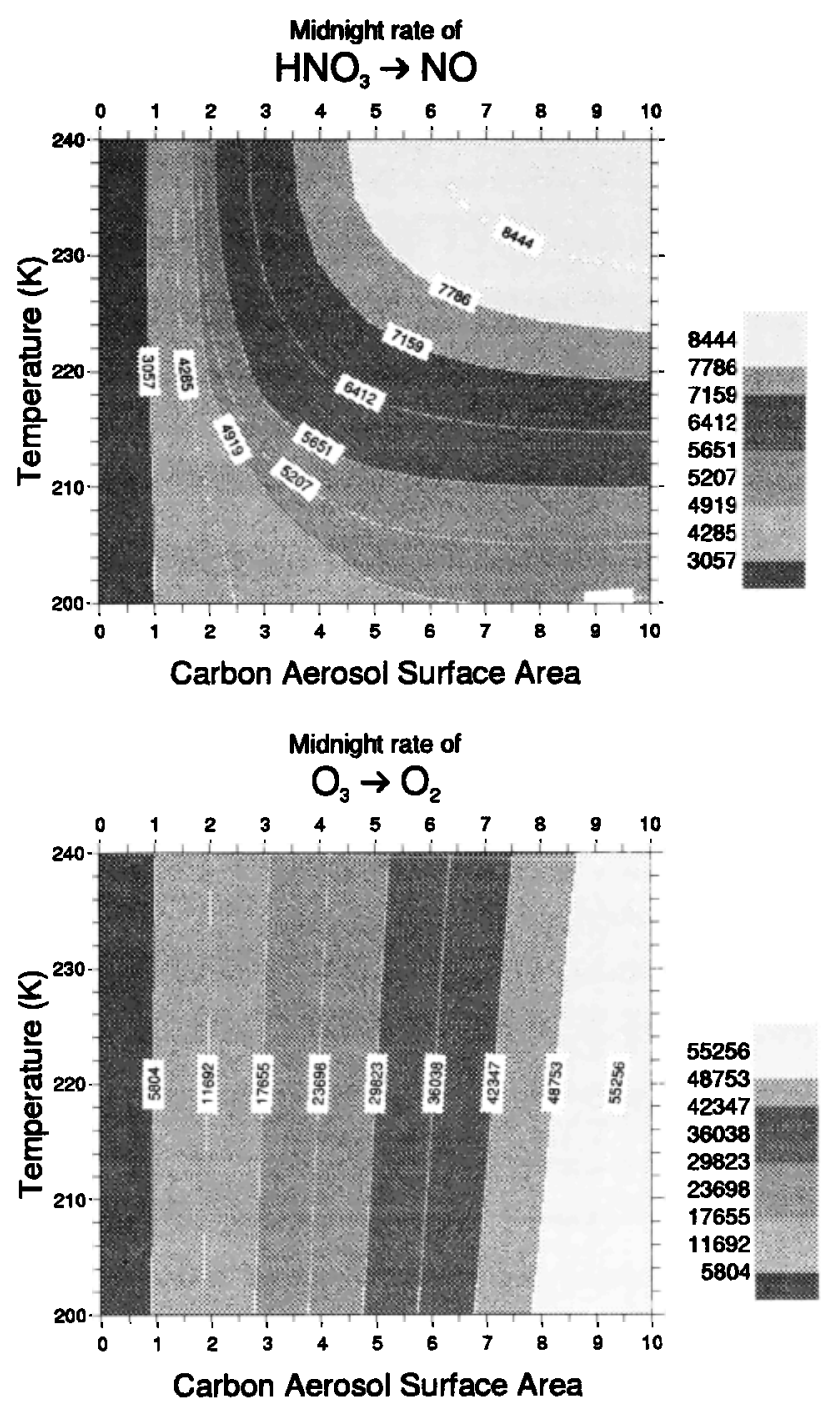

Figure 3. Results for midnight at the end of a set of 7-day simulations. During the 7-day simulations the air parcel was kept at $70 \mathrm{mb}, 45^{\circ} \mathrm{N}$ at equinox. The temperature and amorphous carbon aerosol surface area present were kept constant for each air parcel through out the 7-day period. The results are plotted as a function of temperature (in Kelvin) and the amorphous carbon aerosol surface area in $\mu \mathrm{m}^{2} \mathrm{~cm}^{-3}$. Note that each plot has a different contour interval.

dent. This is in contrast, for example, to the hydrolysis of $\mathrm{N}_{2} \mathrm{O}_{5}$ where although the $\gamma$ value is only weakly temperature dependent, the $\mathrm{N}_{2} \mathrm{O}_{5}$ concentration is strongly temperature dependent. For amorphous carbon aerosol surface areas that are close to the hemispheric average, the additional ozone loss is of the order of $0.3-0.5 \%$ over the period of the 1-week simulation.

Figure 4 shows that the nighttime ozone loss due to the heterogeneous reduction of $\mathrm{HNO}_{3}$ and $\mathrm{NO}_{2}$ has substantially reduced the nighttime ozone lifetime from around 350 months without reduction on carbon to just 52 months with a carbon area of only $1 \mu \mathrm{m}^{2} \mathrm{~cm}^{-3}$.

Heterogeneous reduction of $\mathrm{HNO}_{3}, \mathrm{NO}_{2}$ and $\mathrm{O}_{3}$ therefore represents a potentially important in situ ozone loss mechanism which can operate throughout the day at all latitudes in the lower stratosphere and upper tropo- sphere, irrespective of the temperature, and it is likely that it contributes to the observed ozone trends. This mechanism will increase in importance with the increase in the abundance of carbon aerosol. It is therefore a mechanism that must be accounted for when considering the impact of increased air transport and all combustion processes on the atmosphere.

\section{Altitude Dependence}

In the second set of sensitivity experiments the altitude of the air parcel was varied between 10 and $25 \mathrm{~km}$. Figure 5 shows the additional $\mathrm{O}_{3}$ loss caused by including the heterogeneous reduction of $\mathrm{HNO}_{3}$ and $\mathrm{NO}_{2}$ on amorphous carbon aerosol as a function of altitude and carbon aerosol surface area. It is immediately apparent that in the stratosphere the enhanced levels of $\mathrm{NO}_{x}$ lead 

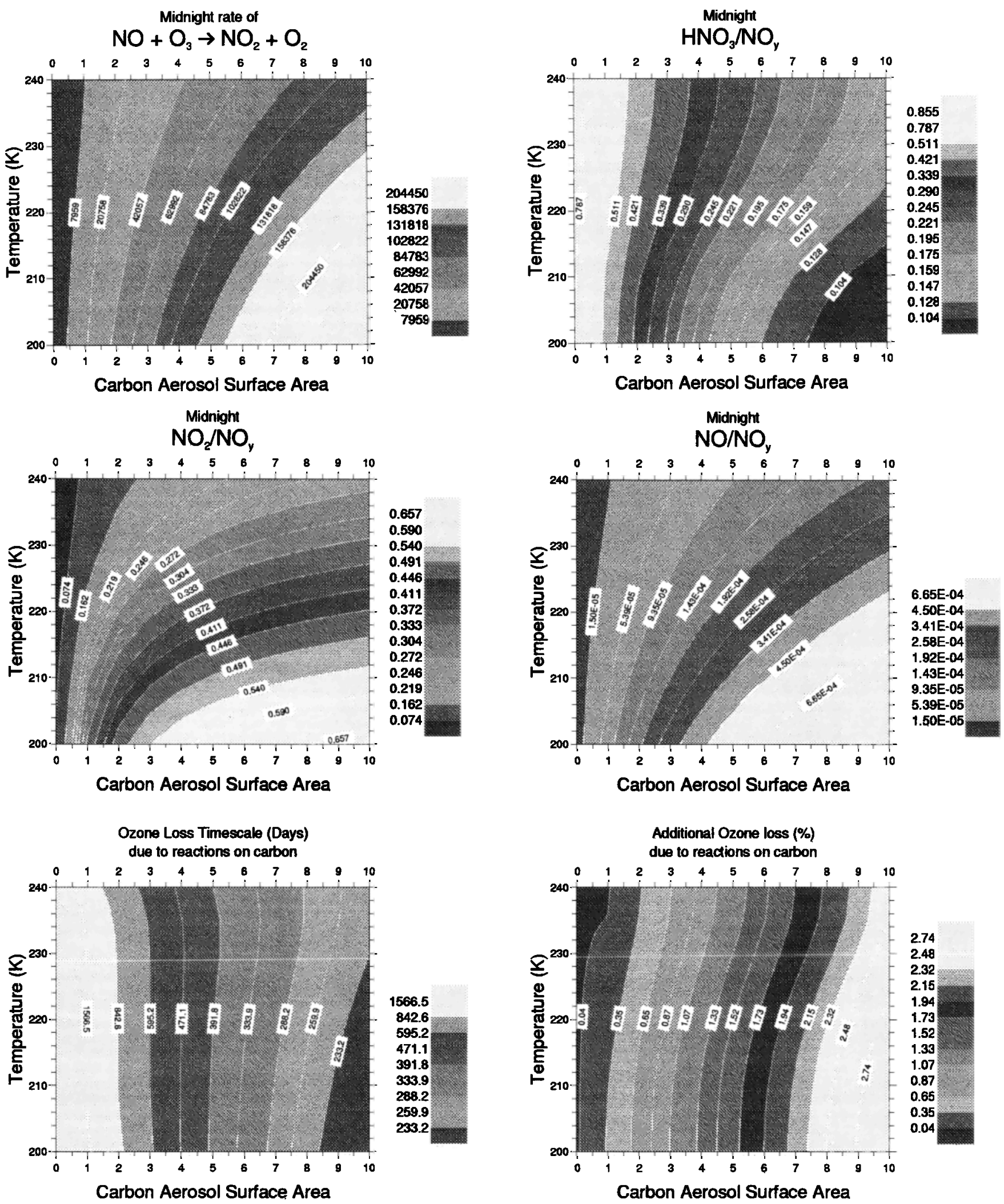

Figure 4. Additional results for midnight at the end of a set of 7-day simulations. During the seven day simulations the air parcel was kept at $70 \mathrm{mb}, 45^{\circ} \mathrm{N}$ at equinox. The temperature and amorphous carbon aerosol surface area present were kept constant for each air parcel through out the 7-day period. The results are plotted as a function of temperature (in Kelvin) and the amorphous carbon aerosol surface area in $\mu \mathrm{m}^{2} \mathrm{~cm}^{-3}$. Note that each plot has a different contour interval. The $\mathrm{NO} / \mathrm{NO}_{y}, \mathrm{NO}_{2} / \mathrm{NO}_{y}$ and $\mathrm{HNO}_{3} / \mathrm{NO}_{y}$ ratios are dimensionless. The $\mathrm{O}_{3}$ loss time-scale at midnight is in units of days. The additional $\mathrm{O}_{3}$ loss caused by including the heterogeneous reactions on amorphous carbon aerosol over the 7 day simulation period is shown as a percentage. 

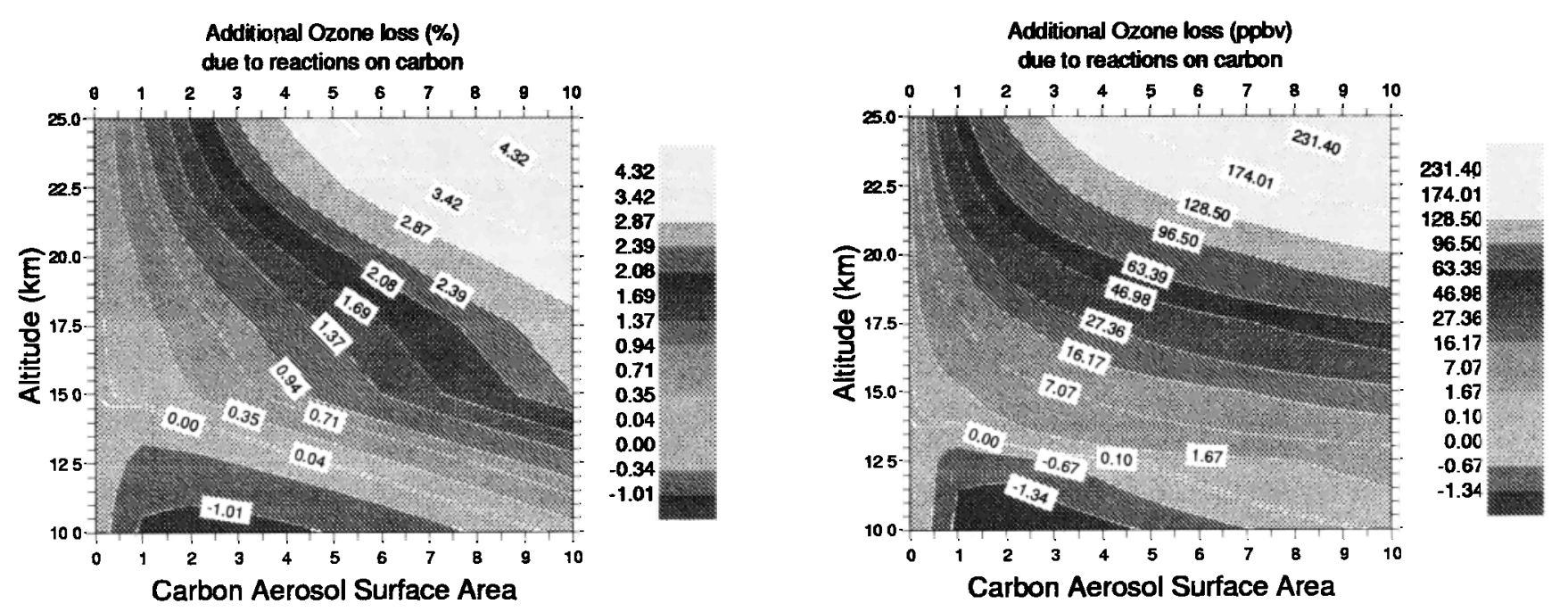

Figure 5. The altitude and area dependence of $\mathrm{O}_{3}$ loss by the amorphous carbon aerosol mechanism. Negative values correspond to an ozone production. (left) Additional $\mathrm{O}_{3}$ loss caused by including the heterogeneous reactions on amorphous carbon aerosol (in percent) over the 7-day simulation period. (Right) Additional $\mathrm{O}_{3}$ loss caused by including the heterogeneous reactions on amorphous carbon aerosol (in ppbv) over the 7-day simulation period.

to ozone loss, whereas in the troposphere the enhanced levels of $\mathrm{NO}_{x}$ lead to ozone production.

As there is much more carbon aerosol in the northern hemisphere than there is in the southern hemisphere, the heterogeneous reduction of $\mathrm{HNO}_{3}, \mathrm{NO}_{2}$, and $\mathrm{O}_{3}$ on amorphous carbon aerosol will give rise to different trends in the northern hemisphere and southern hemisphere. In the troposphere the renoxification that occurs on carbon aerosols would tend to increase the ozone concentration. If the carbon aerosols present are entrained within droplets, then the behavior may be quite different; this also needs to be examined.

Owing to the shape of the ozone and $\mathrm{NO}_{y}$ profiles the largest additional $\mathrm{O}_{3}$ loss in terms of absolute magnitude is largest at higher altitudes. Therefore, if amorphous carbon aerosol can be transported from the aircraft flight corridors up to $25 \mathrm{~km}$, there will be a corresponding effect on the $\mathrm{O}_{3}$ loss rate. Carbon aerosols are much smaller and lighter than sulphate aerosols, and if, as suggested by Blake and Kato [1995], most of the soot is not within sulphate aerosols, there is the possibility that the carbon aerosol residence time is long enough to allow them to reach the midstratosphere. This may be, in part, due to their fractal surface area, which means that they sediment much slower than a sphere of the same mass. If this is the case, they may be able to influence stratospheric chemistry, even up to $30 \mathrm{~km}$. There may be some indication of this in the comparison of ATMOS data and simulations presented in Figure 2.

Figure 5 shows that increasing the carbon surface area from just $0 \mu \mathrm{m}^{2} \mathrm{~cm}^{-3}$ to $1 \mu \mathrm{m}^{2} \mathrm{~cm}^{-3}$ has a marked effect on stratospheric ozone loss and tropospheric ozone production. Observations show that carbon aerosols are definitely present in the midlatitude lower stratosphere between 12 and $20 \mathrm{~km}$. In relative terms, it can be seen from Figure 5 that the additional $\mathrm{O}_{3}$ loss caused by including the heterogeneous reduction of $\mathrm{HNO}_{3}$ and $\mathrm{NO}_{2}$ on amorphous carbon aerosol is significant in this region. Solomon et al. [1996] showed that when a two-dimensional model is constrained with time-varying aerosol observations the shape of the observed trends in ozone is reproduced, but their magnitude is about $50 \%$ larger than that which is observed. The presence of soot in the midlatitude lower stratosphere may help to explain part of this discrepancy between ozone observations and simulations.

Since gas phase $\mathrm{HNO}_{3}$ destruction is so slow, any process that is a sink of $\mathrm{HNO}_{3}$ is potentially significant.

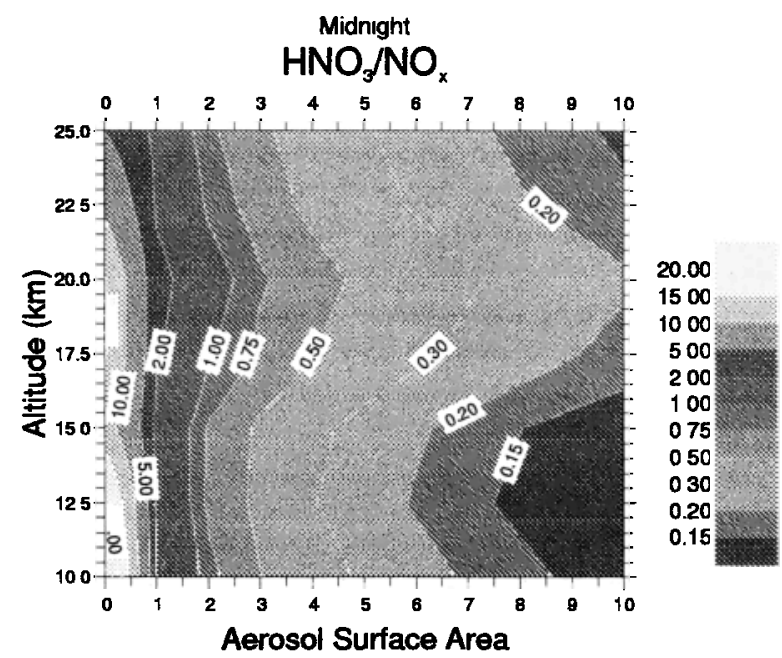

Figure 6. The simulated midlatitude $\mathrm{HNO}_{3} / \mathrm{NO}_{x}$ ratio as a function of altitude and carbon surface area. 

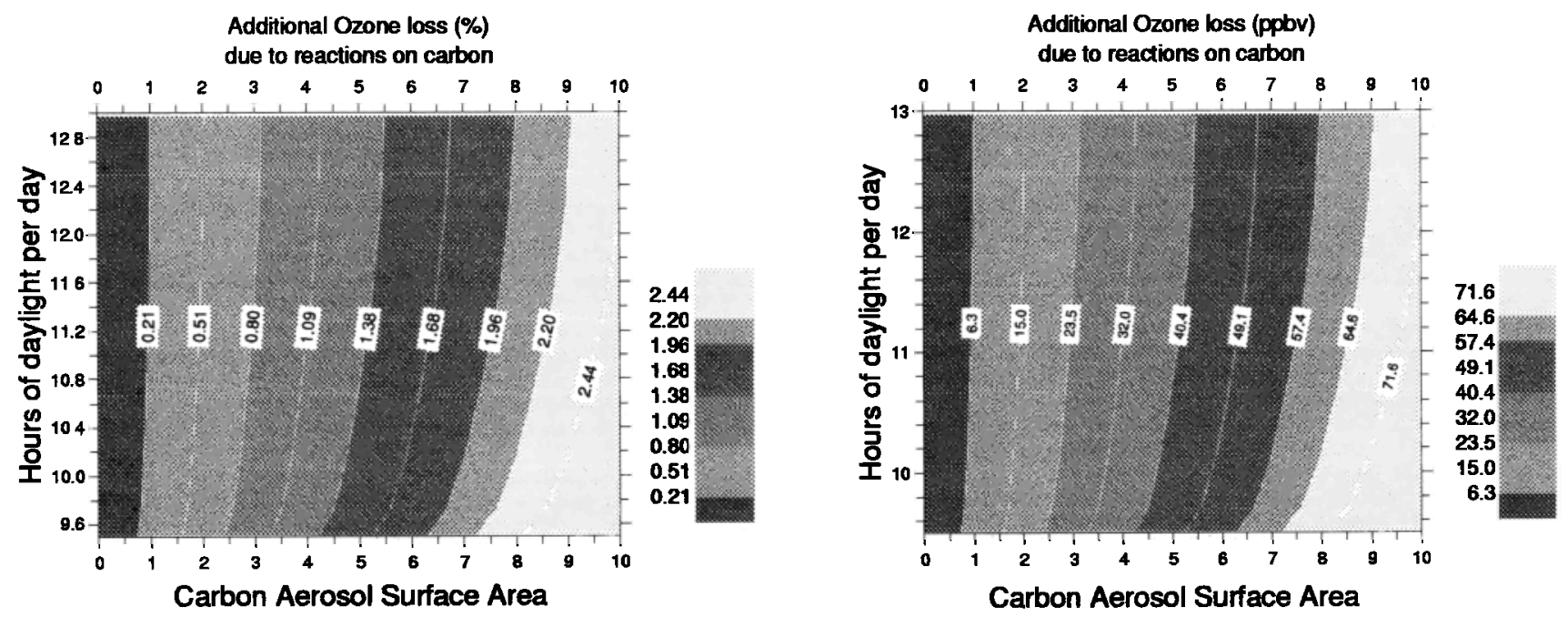

Figure 7. The seasonal dependence of $\mathrm{O}_{3}$ loss by the amorphous carbon aerosol mechanism. (Left) Additional $\mathrm{O}_{3}$ loss caused by including the heterogeneous reduction of $\mathrm{NO}_{2}$ on amorphous carbon aerosol (in percent) over a 7-day simulation. (Right) Additional $\mathrm{O}_{3}$ loss caused by including the heterogeneous reduction of $\mathrm{NO}_{2}$ on amorphous carbon aerosol (in ppbv) over a 7-day simulation.

Figure 6 shows that increasing the carbon surface area from just 0 to $1 \mu \mathrm{m}^{2} \mathrm{~cm}^{-3}$ reduces the $\mathrm{HNO}_{3} / \mathrm{NO}_{x}$ ratio by a factor of about 8 . Chatfield [1995] states that the average free tropospheric $\mathrm{HNO}_{3} / \mathrm{NO}_{x}$ ratio is between 1 and 9 . As can be seen from Figure 6, this is entirely consistent with these simulations. It is also clear that increasing the carbon surface area will substantially increase $\mathrm{NO}_{x}$ and the oxidizing capacity of the troposphere (Figure 5).

\section{Seasonal Dependence}

To investigate the seasonal dependence of the mechanism, the third set of sensitivity experiments allowed the time of year to vary between the summer solstice and the winter solstice. This corresponds to a day length of between 9.5 and 13 hours for an air parcel at $45^{\circ} \mathrm{N}$ in the lower stratosphere. Figure 7 shows that for relatively high carbon surface areas the additional $\mathrm{O}_{3}$ loss caused by including the heterogeneous reduction of $\mathrm{NO}_{2}$ on amorphous carbon aerosol increases by moving from the summer solstice to the winter solstice, whereas at lower carbon surface areas there is little variation with day length. So the relative importance of the mechanism tends to increase with the length of the night for high carbon aerosol loadings. At higher latitudes the mechanism may lead to less ozone loss at some times, as there will be more $\mathrm{NO}_{2}$ present to deactivate reactive chlorine, this will, in turn, lead to higher $\mathrm{ClONO}_{2}$ concentrations.

\section{Summary}

If $\mathrm{HNO}_{3}$ and $\mathrm{NO}_{2}$ are heterogeneously reduced on atmospheric amorphous carbon aerosols produced by, for example, the combustion of fuel from commercial air traffic, then a significant renoxification mechanism exists. This mechanism leads to ozone loss in the stratosphere and ozone production in the troposphere. The stratospheric ozone loss mechanism is almost independent of temperature and does not require the presence of sunlight. The mechanism can operate at all latitudes where amorphous carbon aerosols are present. The relative importance of the mechanism increases slightly with nightlength. Including the heterogeneous reduction of $\mathrm{HNO}_{3}$ and $\mathrm{NO}_{2}$ in model simulations predicts a free tropospheric and stratospheric $\mathrm{HNO}_{3} / \mathrm{NO}_{x}$ ratio that is in good agreement with observations.

Further laboratory studies are urgently required to precisely quantify the rate of reduction and investigate other possible heterogeneous reactions on atmospheric amorphous carbon aerosols. For example, chlorine and bromine species such as $\mathrm{HOCl}$ and $\mathrm{HOBr}$ may also be reduced on carbon aerosols. Further field measurements are required to precisely quantify the amount of amorphous carbon aerosols present in the atmosphere. An assessment of the impact of carbon entrained within water or sulphuric acid droplets is also required.

Acknowledgments. David Lary is a Royal Society University Research Fellow and wishes to thank the Royal Society for its support wishes. He also thanks J.A. Pyle for his support and Robert MacKenzie, and Dudley Shallcross for very useful conversations. The Centre for Atmospheric Science is a joint initiative of the Department of Chemistry and the Department of Applied Mathematics and Theoretical Physics. This work forms part of the NERC UK Universities Global Atmospheric Modelling Programme.

\section{References}

Baumgardner, D., J. E. Dye, B. Gandrud, K. Barr, K. Kelly, and K. R. Chan, Refractive, indexes of aerosols in the 
upper troposphere and lower stratosphere, Geophys. Res. Lett., 23 (7), 749-752, 1996.

Barrie, L. A., et al., The influence of mid-latitudinal pollution sources on haze in the Canadian Arctic, Atmos. Environ., 15, 1407-1419, 1981.

Berry, M. V., Falling fractal flakes, Physica D, 38(1-3), 2931, 1989 .

Blake, D. F., and K. Kato, Latitudinal distribution of black carbon soot in the upper troposphere and lower stratosphere, J. Geophys. Res., 100 (D4), 7195-7202, 1995.

Cess, R. D., Arctic aerosols - model estimates of interactive influences upon the surface atmosphere clear-sky radiation budget, Atmos. Environ., 17, 2555-2564, 1983.

Chatfield, R. B., Anomalous $\mathrm{HNO}_{3} / \mathrm{NO}_{x}$ ratio of remote tropospheric air - Conversion of $\mathrm{HNO}_{3}$ to formic-acid and $\mathrm{NO}_{x}$, Geophys. Res. Lett., 21 (24), 2705-2708, 1995.

Chipperfield, M. P., M. L. Santee, L. Froidevaux, G. L. Manney, W. G. Read, J. W. Waters, A. E. Roche, and J. M. Russell, Analysis of UARS data in the southern polar vortex in september 1992 using a chemical-transport model, J. Geophys. Res., 101(D13), 8861-18881, 1996.

Colbeck, I., and S. Nyeki, Optical and dynamical investigations of fractal clusters, Sci. Prog. Oxford, 76, 149-166, 1992.

Considine, D. B., A. R. Douglass, and R. S. Stolarski, Heterogeneous conversion of $\mathrm{N}_{2} \mathrm{O}_{5}$ to $\mathrm{HNO}_{3}$ on background stratospheric aerosols - comparisons of model results with data, Geophys. Res. Lett., 19 (4), 397-400, 1992.

DeMore, W. B., et al., Chemical kinetics and photochemical data for use in stratospheric modeling, Evaluation Number 10, Jet Propul. Lab., Pasedena, Calif., Publication 94-26, 1994.

Fendel, W., D. Matter, H. Burtscher, and A. Schmidtott, Interaction between carbon or iron aerosol-particles and ozone, Atmos. Environ., 29, 967-973, 1995.

Fendel, W., A. S. Ott, J. Aerosol Sci., 24, S317-S318, 1993.

Fisher, M., and D. J. Lary, Lagrangian four dimensional variational data assimilation of chemical species, $Q . J . R$. Meteorol. Soc., 121(527) Part A, 1681-1704, 1995.

Heintzenberg, J., Size-segregated measurements of particulate elemental carbon and aerosol light-absorption at remote Arctic locations, Atmos. Environ., 16(10), 2461$2469,1982$.

Hansen, A. D. A., and H. Rosen, Vertical distributions of particulate carbon, sulfur, and bromine in the arctic haze and comparison with ground-level measurements at Barrow, Alaska, Geophys. Res. Lett., 11(5), 381-384, 1984.

Hermann, O., et al., Correlative balloon measurements of the vertical distribution of $\mathrm{N}_{2} \mathrm{O}, \mathrm{NO}, \mathrm{NO}_{2}, \mathrm{NO}_{3}, \mathrm{HNO}_{3}$, $\mathrm{N}_{2} \mathrm{O}_{5}, \mathrm{ClONO}_{2}$ and total reactive $\mathrm{NO}_{y}$ inside the polar vortex during SESAME, Proceedings of the Third European Symposium on Stratospheric Ozone, Schliersee, Germany, September 18-22, 1995, in press 1996.

Kärcher, B., T. Peter, U.M. Biermann, and U. Schumann, The initial composition of jet condensation trails, J. Atmos. Sci., in press, 1996.

Lary, D. J., Gas phase atmospheric bromine photochemistry, J. Geophys. Res., 101(D1), 1505-1516, 1996.

Lary, D. J., M. P. Chipperfield, and R. Toumi, The potential impact of the reaction $\mathrm{OH}+\mathrm{ClO} \rightarrow \mathrm{HCl}+\mathrm{O}_{2}$ on polar ozone photochemistry, J. Atmos. Chem., 21(1), 61-79, 1995.

Lary, D. J., M. P. Chipperfield, R. Toumi, and T. M. Lenton, Atmospheric heterogeneous bromine chemistry, J. Geophys. Res., 101(D1), 1489-1504, 1996.

Logan, J. A., Trends in the vertical distribution of ozone: An analysis of ozonesonde data, J. Geophys. Res., 99(D12), 22553-25585, 1994.

Manney, G.L., L. Froidevaux, J. W. Waters, M. L. Santee, W. G. Reed, D. A. Flower, R. F. Jarnot, and R. W. Zurek,
Arctic ozone depletion observed by UARS MLS during the 1991/92 winter, Geophys. Res. Lett., 23(1), 85-88, 1996.

McElroy, M. B., R. J. Salawitch and K. Minschwaner, The changing stratosphere, Planet. Space Sci., 40(2-3), 373401, 1992.

Newchurch, M. J., et al., Stratospheric NO and $\mathrm{NO}_{2}$ abundances from ATMOS solar-occultation measurements, Geophys. Res. Lett., 23(17), 2373-2376, 1996.

Porch, W. M., and M. C. MacCracken, Parametric study of the effects of arctic soot on solar-radiation, Atmos. Environ., 16, 1365-1371, 1982.

Pusechel, R. F., D. F. Blake, K. G. Snetsinger, A. D. A. Hansen, S. Verma, and K. Kato, Black carbon (soot) aerosol in the lower stratosphere and upper troposphere, Geophys. Res. Lett., 19(16), 1659-1662, 1992.

Rahn, K. A., and R. McCaffrey, On the origin of the winter arctic aerosol, Ann. N.Y. Acad. Sci., 338, 486-503, 1980.

Rogaski, C.A., D.M. Golden, and L.R. Williams, The heterogeneous reaction of $\mathrm{HNO}_{3}$ on model soot compounds, Abstr. Pap. Am. Chem. Soc., 211(1), 141-ANYL, 1996.

Rosen, $\mathrm{H}$, and A. D. A. Hansen, Role of combustiongenerated carbon particles in the absorption of solarradiation in the Arctic haze, Geophys. Res. Lett., 11(5), 461-464, 1984.

Rosen, H., T. Novakov, and B. A. Bodhaine, Soot in the Arctic, Atmos. Environ., 15, 1371-1374, 1981.

Rosen, H., and T. Novakov, Combustion-generated carbon particles in the Arctic atmosphere, Nature, 306 (5945), 768-770, 1983.

Schumann, U., Impact of emissions from aircraft and spacecraft upon the atmosphere - An introduction, Paper presented at International Scientific Colloguium, Cologne, Germany, April 18-20, 1994.

Shaw, G. E., and K. Stamnes, Arctic haze: Perturbation of the polar radiation budget, Ann. N.Y. Acad. Sci., 398, 533-539, 1980.

Smith, D.M., W.F. Welch, J.A. Jassim, A.R. Chughtai, and D.H. Stedman, Soot-ozone reaction kinetics - Spectroscopic and gravimetric studies, Appl. Spectros., 42(8), 1473-1482, 1988.

Solomon, S., R. W. Portmann, R. R. Garcia, L. W. Thomason, L. R. Poole, and M. P. McCormick, The role of aerosol variations in anthropogenic ozone depletion at northern mid-latitudes, J. Geophys. Res., 101(D3), 67136727, 1996.

Stephens, S., M.J. Rossi, and D.M. Golden, The heterogeneous reaction of ozone on carbonaceous surfaces, Int. J. Chem. Kinetics, 18(10), 1133-1149, 1986.

Stonehouse, B., Arctic Air Pollution - Studies in Polar Research, Cambridge Univ. Press, 1986.

Tabor, K., L. Gutzwiller, and M. J. Rossi, The heterogeneous interaction of $\mathrm{NO}_{2}$ with amorphous-carbon, Geophys. Res. Lett., 20(14), 1431-1434, 1993.

Tabor, K., L. Gutzwiller, and M. J. Rossi, The heterogeneous interaction of $\mathrm{NO}_{2}$ with amorphous-carbon at ambient temperature, J. Phys. Chem., 98(24), 6172-6186, 1994.

Thlibi, J., and J. C. Petit, A study of the $\mathrm{NO}_{y} /$ Soot interaction in the temperature range 303-1223 K, Paper presented at International Scientific Colloquium, Cologne, Germany, April 18-20, 1994.

Toumi, R., S. Bekki and R. Cox, A model study of ATMOS observations and the heterogeneous loss of $\mathrm{N}_{2} \mathrm{O}_{5}$ by the sulfate aerosol layer, J. Atmos. Chem., 16(2), 135-144, 1993.

World Meteorological Organisation, Scientific assessment of stratospheric ozone: 1991, Rep. 25, WMO Global Ozone Res. and Monit. Proj., Geneva, 1992.

World Meteorological Organisation, Scientific assessment of 
stratospheric ozone: 1994, Rep. 37, WMO Global Ozone Res. and Monit. Proj., Geneva, 1994.

D. J. Lary and A. M. Lee, Centre For Atmospheric Science, Department of Chemistry, Cambridge University, Lensfield Road, Cambridge, CB2 1EW, England. (e-mail: david@atm.ch.cam.ac.uk)

M. J. Newchurch, Earth System Science Lab., University of Alabama in Huntsville, Huntsville, AL 35899, U.S.A.
M. Pirre and J. B. Renard, Laboratoire de Phsyique et Chimie de l'Environement. CNRS, Orleans, France.

R. Toumi, Department of Physics, Imperial College, London, SW7 2BZ, England.

(Received November 22, 1995; revised August 26, 1996; accepted August 26, 1996.) 